3) The significance of sampling, sampling resolution

This issue has two aspects: a) sediments are sampled to establish the $\left({ }^{210} \mathrm{~Pb}\right)$ chronology. Stratigraphic sampling according to sedimentary microfacies substantially improves the quality of ${ }^{210} \mathrm{~Pb}$ chronologies (Arnaud et al., 2002). Layers with rapid sedimentation (e.g., turbidites) need to be excluded; and b) samples for the analysis of the lake sediment proxies must be taken continuously and, ideally, at annual resolution, at least throughout the calibration period. This is the basic requirement to target e.g., sub-decadal climate variability (such as ENSO cycles).

Therefore, the sediment core that is used to establish the proxy data must not be cut before the chronology for the calibration period is fully established, and sampling intervals along the sediment core should be adjusted according to local sedimentation rates. Furthermore, the core used to establish the chronology and the one used to produce the proxy data series must have a perfect micro-stratigraphic match at the millimeter-scale. In practice, this is only possible on two halves of one split core, or on varved sediments. In this context, the advantage of using non-destructive methods (XRF scanning or in-situ reflectance spectroscopy scanning (Kalugin et al., 2007; Rein and Sirocko, 2002; von Gunten et al., 2009a; Fig. 2)) is obvious.

Conclusion 3:

Establish the chronology of the calibration period first, and sample the sediments for the proxy analyses afterwards (according to the chronology).

4) Sampling resolution, analysis of the meteorological data

Ultra fine "technical" sampling resolution does not necessarily correspond to the "true" resolution of (climate) variability recorded in the sediments. For a number of reasons (dating and sampling errors, synchronizing of proxy data points to a calendar scale with homogenous temporal resolution) raw proxy series must be filtered. As a rule of thumb, the resolution of the raw data series should be 3-4 times higher than the final resolution (highest frequency band of climate variability) envisaged. System-inherent filters, such as bioturbation may destroy the highest true (or meaningful) temporal resolution of climate variability that is potentially recorded in a lake. Thus, this type of research should actually start with the statistical analysis of the local meteorological time series, and calculate the sampling resolution that is required to detect the dominant features of variability, trends and extremes of the local climate.

\section{Conclusion 4:}

The "technical" and the "true" sampling resolution, and the "envisaged" (best possible) temporal resolution of the climate reconstruction have their restrictions. These must be carefully assessed.

\section{5) The properties of the calibration period}

Obviously, all the caveats for regressionbased reconstructions also apply to a calibration-in-time (e.g., non-modern analogues, long-term trends). Furthermore, the length of the instrumental meteorological time series is often limited. Moreover, many of the calibration parameters (starting and ending point, data homogenization, selection of the split periods for cross validation, etc.) are an optimization process and an expert choice. Instead of using split periods, it might be justified to use the entire meteorological data series for a proper calibration. In addition, the use of reanalysis data sets should be considered and tested (e.g., ICOADS http:// www.cdc.noaa.gov/data/ or ACRE http:// www.met-acre.org/) in areas where instrumental series are very short. Shorter calibration periods often exhibit pronounced (warming) trends, which is a problem for the calibration statistics.

Conclusion 5:

The choice of the appropriate calibration (period and parameters) is not a priori known. A novel approach would be to produce probabilistic reconstructions based on an ensemble of different calibrations.

\section{Conclusions and outlook}

New developments in scanning techniques have boosted the acquisition of high-resolution biogeochemical proxies from lake sediments. Faced with the challenges mentioned above, these data must be converted into quantitative climate (environmental) variables using calibration-in-time. We have shown here that this task can be accomplished; yet, it requires careful consideration and planning of the practical work, further refining of the methodology (as proposed above), as well as systematic exploration of the potentials and limits of the individual methods used.

\section{References}

Appleby, P.G., 2008: Three decades of dating recent sediments by fallout radionuclides: a review, Holocene, 18: 83-93.

Carroll, J. and Lerche, I., 2003: Sedimentary processes: quantification using radionuclides, Elsevier, Oxford

Trachsel, M., Eggenberger, U., Grosjean, M., Blass, A. and Sturm, M. 2008: Mineralogy-based quantitative precipitation and temperature reconstructions from annually laminated lake sediments (Swiss Alps) since AD 1580, Geophysical Research Letters, 35(13): L13707.

von Gunten, L., Grosjean, M., Rein, B., Urrutia, R. and Appleby, P., 2009a: A quantitative high-resolution summer temperature reconstruction based on sedimentary pigments from Laguna Aculeo, central Chile, back to AD 850, The Holocene, 19(6): 873-881.

von Gunten, L., Grosjean, M., Beer, J., Grob, P., Morales, A. and Urrutia, R., 2009b: Age modeling of young non-varved lake sediments: methods and limits. Examples from two lakes in Central Chile, Journal of Paleolimnology, D0l 10.1007/s10933-008-9284-5.

\title{
Environmental and climatic changes inferred from lake deposits in China: A review of recent progress
}

\author{
Patrick Rioual and Luo Wang \\ Key Laboratory of Cenozoic Geology and Environment, Institute of Geology and Geophysics, Chinese Academy of Sciences, Beijing, China; \\ prioual@mail.igcas.ac.cn
}

\section{In recent years, Chinese paleoscience including paleolimnology has made huge progress, providing a wealth of data on past environmental and climatic change on various timescales. A brief review is presented here on recent research based on Chinese lake sediment records and their significance in the PAGES context.}

\section{Climate records in the arid areas of northwestern China}

A large share of paleolimnological research in China has focused on climate records from lakes located in the vast arid and semi-arid areas of northern and west- ern China, which include the regions of Inner Mongolia, Xinjiang, Qinghai and Tibet. These climate records are concerned with changes in precipitation or effective moisture. Most of these lakes are brackish or saline and often very shallow (Fig.
1A). The most commonly used proxies are pollen, stables isotopes $\left(\delta^{13} \mathrm{C}, \delta^{18} \mathrm{O}\right)$, ostracods, grain size and various geochemical variables. Because of bad preservation in these saline, highly alkaline and shallow lakes, biological proxies, such as diatoms, 


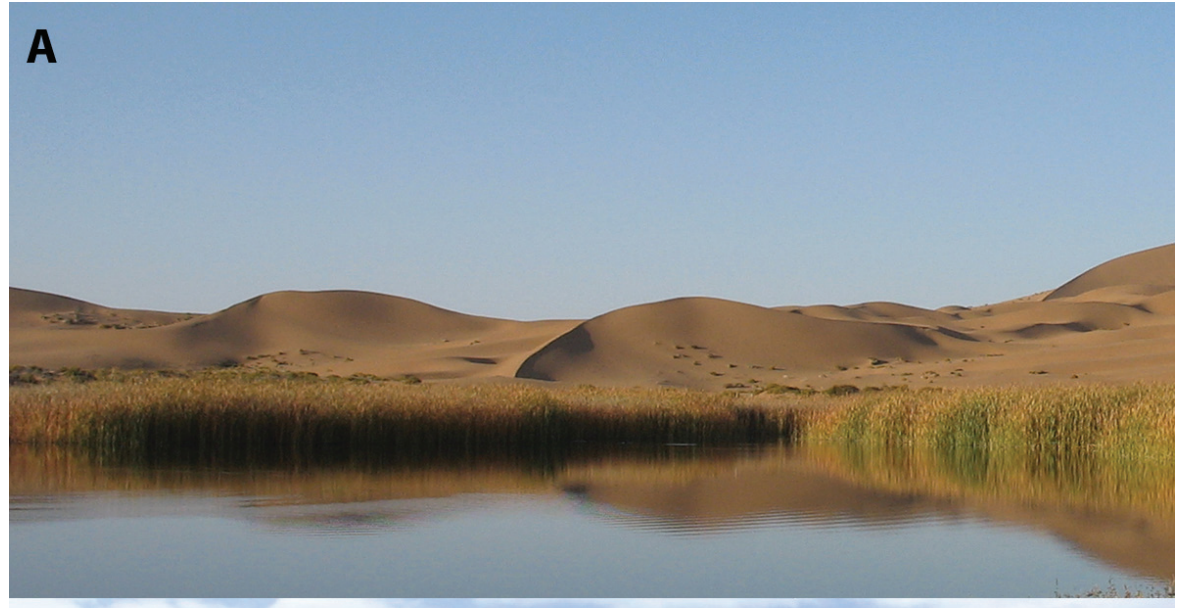

B

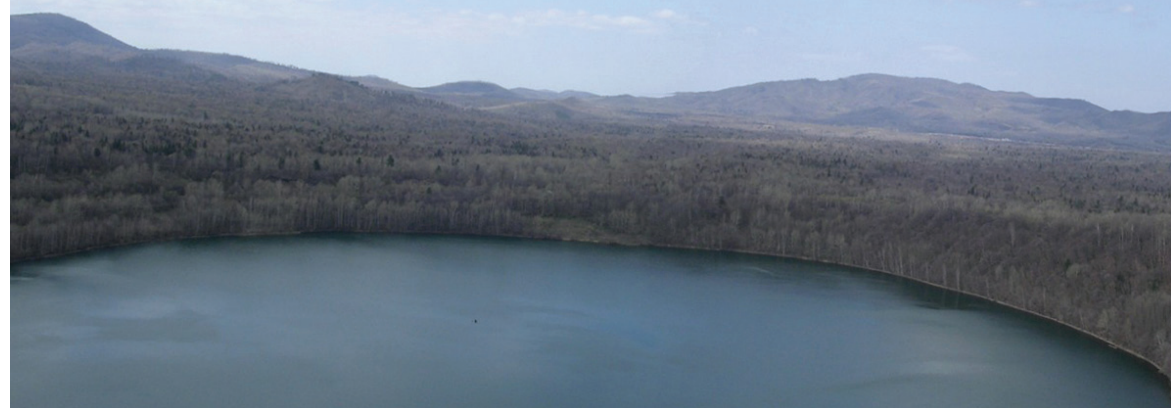

Figure 1: Contrasting lakes from China. A) A shallow, brackish lake from the Badan Jilin desert in Inner Mongolia B) Sihailongwan Lake, a deep maar lake in northeastern China.

can seldom be used on long sediment sequences. In the most recent review on this topic, Chen et al. (2008) used a selection of the most reliably dated lake sediment records from northern China to summarize the changes in moisture during the Holocene. They found that in arid China the early Holocene was characterized by dry conditions, the mid-Holocene was less dry whereas the late Holocene was moderately wet. A similar pattern is reported from north central China (Xiao et al., 2004; 2008). Therefore, the Holocene moisture history in arid China appears to be out-of-phase with that of areas located further south and east, which are under the influence of the Asian summer monsoon. As shown by many paleoclimate records, such as the pollen records from southern China (Shen et al., 2006; Wang et al., 2007) and the stalagmite records of central and southeastern China (Wang et al., 2005; Cosford et al., 2008), a humid climate characterized the early Holocene in monsoonal China, whereas drier climates prevailed during the late Holocene. These changes were driven by variations in lowlatitude summer insolation. By contrast, the changes observed in the lake records of arid China appear correlated with North-Atlantic sea-surface temperatures, which indicate an atmospheric teleconnection via the Westerlies. and monsoonal activities over the past 18 ka (Ji et al., 2009).

\section{Paleolimnology in maar and crater lakes}

Among the lacustrine records, those from crater and maar lakes are often considered to be especially well suited for paleoenvironmental studies because volcanic lakes are generally small and simple systems (in terms of hydrology and morphology) that appear to be more favorable for the evaluation of paleolimnological records than large and complex lakes (Baier et al., 2004). Starting in the late 1990s, a collaborative project between Chinese and German scientists aimed at studying the numerous Chinese maar lakes for paleoclimatic reconstructions (see Liu et al., in PAGES news, July 2001).

In southern China, the Huguang maar lake sediment record has been intensively studied. Yancheva et al. (2007) have used sediment Titanium content and magnetic properties as proxies for reconstructing the intensity of the winter monsoon, which consists of dry and cold winds that transport dust particles from the deserts of northern China. The fossil diatom record of Huguang maar lake was analyzed by Wang et al. (2008) (Fig. 2). Sediment trap experiments in the modern lake revealed that the seasonal distribution of the dominant planktonic species, Cyclotella stelligera and Aulacoseira granulata, is controlled by wind-driven turbulence in the water column. During the late Glacial and the Holocene, the same two diatom taxa dominated alternatively in the sediment record. These shifts seem to support Yancheva et al's (2007) interpretation of Ti abundance as a proxy for the winter monsoon winds. However, their assumption that the winter and summer monsoons were anti-correlated on a decadal scale is not supported by historical documents (Zhang and Lu, 2007).

In northeastern China, several maar lakes have been investigated and the presence of annual laminations (varves) in the sediment has been established (Chu et al., 2005; 2008; 2009; You et al., 2008). As the sediment sequences are almost continuously laminated, very robust chronologies could be constructed by varve counting combined with AMS ${ }^{14} \mathrm{C}$ dating. In Lake Sihailongwan (Fig. 1B), the upper $25 \mathrm{~m}$ of the sediment sequence comprise the last 65 ka (Mingram et al., 2007). In this lake, paleolimnological research is well advanced, especially over two time windows: a) the late Glacial and early Holocene for which geochemical (Schettler et al., 2006a; Parplies et al., 2008) and pollen investiga- history of the Tibetan Plateau over the eight millions years. On a much shorter timescale, novel analytical approaches have been used to study Lake Qinghai Holocene history. For example, alkenones were used for the quantitative reconstruction of temperature and salinity over the past 2 ka (Liu et al., 2006), whereas analysis of bacteriophaeophytin pigment abundance yielded past blooms of anaerobic phototrophic bacteria as a proxy for solar 
tions have been completed (Stebich et al., 2009), and b) the late Holocene with geochemical (Schettler et al., 2006b) and minerogenic analyses (Chu et al., 2009). For the late Glacial in particular, short cold/ dry spells were recorded that are perfectly correlated with events reported from the Greenland ice core records. Such synchronicity in abrupt climate shifts demonstrates that the North Atlantic and East Asian regions were strongly coupled via atmospheric teleconnections. The varvebased chronologies that have been established from several lakes also enabled precise determination of the age of several tephra layers preserved in the sediment records, thereby providing a much improved chronology of volcanic eruptions in northeastern China (Liu et al., 2009).

\section{Outlook}

In addition to the research topics outlined above, lake sediment records are also used to investigate the history of eutrophication, especially in the large and shallow floodplain lakes of the middle and lower reaches of the Yangtze River, which is one of the most densely populated and industrialized areas in China. Paleolimnological research on these lakes mainly relies upon diatom-based reconstructions of total phosphorus concentrations in lake water (Yang et al., 2008; Dong et al., 2008). The multi-proxy record from Lake Erhai in Yunnan, southern China, is also an excellent example of how to use lake sediment records to reconstruct climate-human-environment interactions during the Holocene (Dearing et al., 2008).

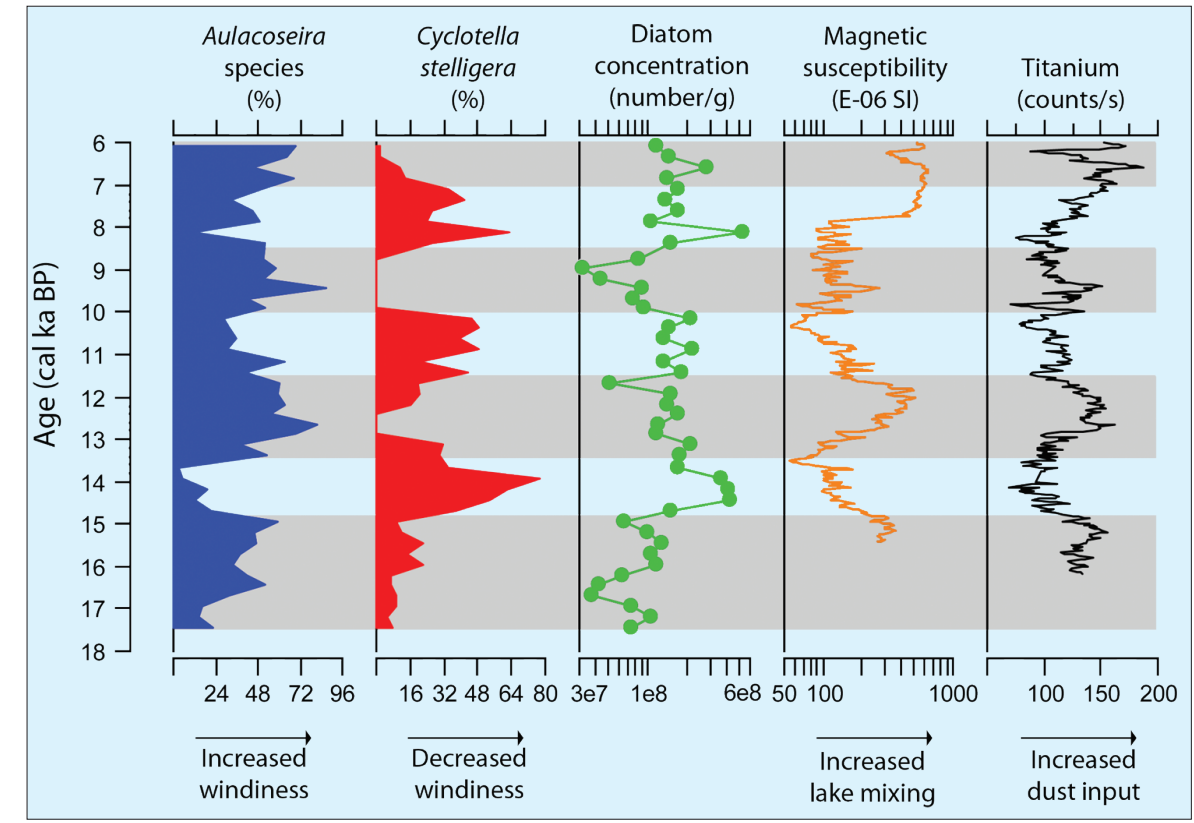

Figure 2: Comparison of the diatom data: \% abundances of the planktonic centric taxa Aulacoseira spp. (blue) and Cyclotella stelligera (red), as well as diatom concentration (green) (Wang et al., 2008), with the titanium (Ti) content (black) and magnetic susceptibility records (orange) (Yancheva et al., 2007) from the Huguang maar lake (South China). High abundances of Aulacoseira spp. are indicative of periods of turbulent water column mixing due to strong winds, while increased abundance of $C$. stelligera suggests thermally stratified, weak wind conditions. The seasonal change in relative abundance of these taxa can, therefore, be used as a proxy of the strength of winter monsoon winds. Ti and magnetic susceptibility are proxies for dust input and lake mixing, respectively.

\section{Acknowledgements}

The authors would like to thank the financial support from the National Science Foundation of China (grants \# 4050 21018, 40872113 and 10572107) and the Chinese Academy of Sciences (grant \# kzcx2-yw-119-02).

\section{References}

Chen, F. et al., 2008: Holocene moisture evolution in arid central Asia and its out-of-phase relationship with Asian monsoon history, Quaternary Science Reviews, 27: 351-364.

Chu, G., Sun, Q., Gu, Z., Rioual, P., Liu, Q., Wang, K., Han, J. and Liu, J., 2009: Dust records from varved lacustrine sediments of two neighboring lakes in northeastern China over the last 1400 years, Quaternary International, 194: 108-118.
Colman, S.M., Yu, S.-Y., An, Z.S., Shen, J. and Henderson, A.C.G., 2007 Late Cenozoic climate changes in China's western interior: a review of research on Lake Qinghai and comparison with other records, Quaternary Science Reviews, 26: 2281-2300.

Wang, L. et al., 2008: Diatom-based inference of variations in the strength of Asian winter monsoon winds between 17,500 and 6000 calendar years B.P., Journal of Geophysical Research, 113. D21101, doi:10.1029/2008JD010145.

Yancheva, G. et al., 2007: Influence of the intertropical convergence zone on the East Asian monsoon, Nature, 445: 74-77.

For full references please consult:

www.pages-igbp.org/products/newsletters/ref2009_3.html

\section{Paleolimnology of African lakes: Beyond the exploration}

\section{phase}

Dirk Verschuren ${ }^{1}$ and James M. Russell ${ }^{2}$

'Limnology Unit, Department of Biology, Ghent University, Belgium; dirk.verschuren@UGent.be Department of Geological Sciences, Brown University, Providence, USA

\section{Longstanding research questions on tropical climate-human-ecosystem interactions can be tackled by combining novel and traditional paleoenvironmental proxies from high-quality sediment archives in African lakes.}

\section{Paleolimnology of African lakes: Something particular}

African lakes have had a special allure to paleolimnologists ever since pioneering work by Dan Livingstone and his students revealed their potential for tropical paleoecology and paleoclimatology. However, it took time before their particularities (e.g., methane-charged muds, unstable sedimentary environments associated with fluctuating lake level) and logistical chal- lenges no longer hampered application of the modern paleolimnological techniques that were developed in Europe and North America during the 1980s. Given the scarcity of annually resolved African lake records, progress in African paleolimnology depends on well-constrained radiometric chronologies. This is often challenging, because lakes with the hydrological sensitivity required to register decade- to century-scale climate variability tend to display significant variability in sedimentation rates and radiocarbon reservoir age, with complicating effects on the agedepth relationship that cannot easily be resolved by ${ }^{210} \mathrm{~Pb} /{ }^{14} \mathrm{C}$-based age models. As for the reconstructions themselves, the principal issues are that, firstly, past human impacts on African lakes and the surrounding landscapes cannot be determined without accounting for major climatic influence on ecosystem dynamics at 


\section{Full Reference List:}

An, Z.S. et al., 2006: Geophysical survey on the tectonic and sediment distribution of Qinghai Lake basin, Science in China Series D Earth Sciences, 49: 851-861.

Baier, J., Lücke, A., Negendank, J.F.W., Schleser, G.H. and Zolitschka, B., 2004: Diatom and geochemical evidence of mid- to late Holocene climatic changes at Lake Holzmaar, West-Eifel (Germany), Quaternary International, 113: 81-96.

Chen, F. et al., 2008: Holocene moisture evolution in arid central Asia and its out-of-phase relationship with Asian monsoon history, Quaternary Science Reviews, 27: 351-364.

Chu, G., Liu, J., Schettler, G., Li, J., Sun, Q., Gu, Z., Lü, H., Liu, Q. and Liu, T., 2005: Sediment fluxes and varve formation in Sihailongwan, a maar lake from northeastern China, Journal of Paleolimnology, 34: 311-324.

Chu, G., Sun, Q., Rioual, P., Boltovskoy, A., Liu, Q., Sun, P., Han, J. and Liu, J., 2008: Dinocyst microlaminations and freshwater "red tides" recorded in Lake Xiaolongwan, northeastern China, Journal of Paleolimnology, 39: 319-333.

Chu, G., Sun, Q., Gu, Z., Rioual, P., Liu, Q., Wang, K., Han, J. and Liu, J., 2009: Dust records from varved lacustrine sediments of two neighboring lakes in northeastern China over the last 1400 years, Quaternary International, 194: 108-118.

Colman, S.M., Yu, S.-Y., An, Z.S., Shen, J. and Henderson, A.C.G., 2007: Late Cenozoic climate changes in China's western interior: a review of research on Lake Qinghai and comparison with other records, Quaternary Science Reviews, 26: 2281-2300.

Cosford, J., Qing, H., Erlington, B., Mattey, D., Yuan, D., Zhang, M. and Cheng, H., 2008: East Asian monsoon variability since the Mid-Holocene recorded in a high-resolution, absolute-dated aragonite speleothem from eastern China, Earth and Planetary Science Letters, 275: 296-307.

Dearing, J.A., Jones, R.T., Shen, J., Yang, X., Boyle, J.F., Foster, G.C., Crook, D.S. and Elvin, M.J.D., 2008: Using multiple archives to understand past and present climate-human-environment interactions: the lake Erhai catchment, Yunnan Province, China, Journal of Paleolimnology, 40: $3-41$.

Dong, X., Bennion, H., Battarbee, R.W., Yang, X., Yang, H. and Liu, E. 2008: Tracking eutrophication in Taihu Lake using diatom record: potential and problems, Journal of Paleolimnology, 40: 413429.

Ji, J., Balsam, W., Shen, J., Wang, M., Wang, H. and Chen, J., 2009: Centennial blooming of anoxygenic phototrophic bacteria in Qinghai Lake linked to solar and monsoon activities during the last 18,000 years, Quaternary Science Reviews, doi.10.1016/j.quascirev.2008.12.015

Liu, J., Liu, T. and Negendank, J.F.W., 2001: The Chinese maar drilling programme. A ChineseGerman cooperation for paleoclimatic reconstructions, Pages News, 9: 10-11.

Liu, Z., Henderson, A.C.G. and Huang, Y., 2006: Alkenone-based reconstruction of late-Holocene surface temperature and salinity changes in Lake Qinghai, China, Geophysical Research Letters, 33: L09707, doi:10.1029/2006GL026151.

Liu, J., Chu, G., Han, J., Rioual, P., Jiao, W. and Wang, K., 2009: Volcanic eruptions in the Longgang volcanic field, northeastern China, during the past 15,000 years, Journal of Asian Earth Sciences, 34: 645-654.

Mingram, J. et al., 2007: East Asian monsoon variability over the last 65,000 years - new insights from laminated lake sediments of NE-China. 3rd Alexander von Humboldt International conference, The East Asian Monsoon, past, present and future, Beijing, China, Abstract volume p14.

Parplies, J., Lücke, A., Vos, H., Mingram, J., Stebich, M., Radtke, U., Han, J. and Schleser, G.H., 2008: Late glacial environment and climate development in northeastern China derived from geochemical and isotopic investigations of the varved sediment record from Lake Sihailongwan (Jilin Province), Journal of Paleolimnology, 40: 471-487.

Schettler, G., Mingram, J., Negendank, J.F.W. and Liu, J., 2006a: Palaeovariations in the East-Asian monsoon regime geochemically recorded in varved sediments of Lake Sihailongwan (Northeast China, Jilin Province). Part 2: a 200-year record of atmpspheric lead-210 flux variations and its palaeoclimatic implications, Journal of Paleolimnology, 35: 271-288.

Schettler, G., Liu, Q., Mingram, J., Stebich, M. and Dulski, P., 2006b: East-Asian monsoon variability between 15000 and $2000 \mathrm{cal}$. yr BP recorded in varved sediments of Lake Sihailongwan (northeastern China, Long Gang volcanic field), The Holocene, 16: 1043-1057. 
Stebich, M., Mingram, J., Han, J. and Liu, J., 2009: Late Pleistocene spread of (cool-) temperate forests in Northeast China and climate changes synchronous with the North Atlantic region, Global and Planetary Change, 65: 56-70.

Shen, J., Jones, R.T., Yang, X., Dearing, J.A. and Wang, S., 2006: The Holocene vegetation history of Lake Erhai, Yunnan province southwestern China: the role of climate and human forcings, The Holocene, 16: 265-276.

Wang, L. et al., 2008: Diatom-based inference of variations in the strength of Asian winter monsoon winds between 17,500 and 6000 calendar years B.P., Journal of Geophysical Research, 113: D21101, doi:10.1029/2008JD010145.

Wang, S., Lü, H., Liu, J. and Negendank, J.F.W., 2007: The early Holocene optimum inferred from a high-resolution pollen record of Huguanyan Maar Lake in southern China, Chinese Science Bulletin, 52: 2829-2836.

Wang, Y. et al., 2005: The Holocene Asian monsoon: links to solar changes and North Atlantic climate, Science, 308: 854-857.

Xiao, J., Xu, Q., Nakamura, T., Yang, X., Liang, W. and Inouchi, Y., 2004: Holocene vegetation variation in the Dahai Lake region of north-central China: a direct indication of the Asian monsoon climatic history, Quaternary Science Reviews, 23: 1669-1679.

Xiao, J., Si, B., Zhai, D., Itoh, S. and Lomtatidze, Z., 2008: Hydrology of Dali Lake in central-eastern Inner Mongolia and Holocene East Asian monsoon variability, Journal of Paleolimnology, 40: 519-528.

Yancheva, G. et al., 2007: Influence of the intertropical convergence zone on the East Asian monsoon, Nature, 445: 74-77.

Yang, X., Anderson, N.J., Dong, X. and Shen, J., 2008: Surface sediment diatom assemblages and epilimnetic total phosphorus in large, shallow lakes of the Yangtze floodplain: their relationships and implications for assessing long-term eutrophication, Freshwater Biology, 53: 1273-1290.

You, H., Liu, J., Liu, Q., Chu, G., Rioual, P. and Han, J., 2008: Study of the varve record from Erlongwan maar lake, NE China, over the last 13 ka BP, Chinese Science Bulletin, 53: 262-266.

Zhang, D. and Lu, L., 2007: Anti-correlation of summer/winter monsoons? Nature, 450: E7-E9. 